\title{
Breast tumor specific mutation in GATA3 affects physiological mechanisms regulating transcription factor turnover
}

\author{
Aleksandra B Adomas', Sara A Grimm², Christine Malone ${ }^{1}$, Motoki Takaku', Jennifer K Sims ${ }^{1}$ and Paul A Wade ${ }^{1 *}$
}

\begin{abstract}
Background: The transcription factor GATA3 is a favorable prognostic indicator in estrogen receptor-a (ERa)-positive breast tumors in which it participates with ERa and FOXA1 in a complex transcriptional regulatory program driving tumor growth. GATA3 mutations are frequent in breast cancer and have been classified as driver mutations. To elucidate the contribution(s) of GATA3 alterations to cancer, we studied two breast cancer cell lines, MCF7, which carries a heterozygous frameshift mutation in the second zinc finger of GATA3, and T47D, wild-type at this locus.

Methods: Immunofluorescence staining and subcellular fractionation were employed to verify cellular localization of GATA3 in T47D and MCF7 cells. To test protein stability, cells were treated with translation inhibitor, cycloheximide or proteasome inhibitor, MG132, and GATA3 abundance was measured over time using immunoblot. GATA3 turn-over in response to hormone was determined by treating the cells with estradiol or ERa agonist, ICI 182,780. DNA binding ability of recombinant GATA3 was evaluated using electrophoretic mobility shift assay and heparin chromatography. Genomic location of GATA3 in MCF7 and T47D cells was assessed by chromatin immunoprecipitation coupled with next-generation sequencing (ChIP-seq).

Results: GATA3 localized in the nucleus in T47D and MCF7 cells, regardless of the mutation status. The truncated protein in MCF7 had impaired interaction with chromatin and was easily released from the nucleus. Recombinant mutant GATA3 was able to bind DNA to a lesser degree than the wild-type protein. Heterozygosity for the truncating mutation conferred protection from regulated turnover of GATA3, ERa and FOXA1 following estrogen stimulation in MCF7 cells. Thus, mutant GATA3 uncoupled protein-level regulation of master regulatory transcription factors from hormone action. Consistent with increased protein stability, ChIP-seq profiling identified greater genome-wide accumulation of GATA3 in MCF7 cells bearing the mutation, albeit with a similar distribution across the genome, comparing to T47D cells.
\end{abstract}

Conclusions: We propose that this specific, cancer-derived mutation in GATA3 deregulates physiologic protein turnover, stabilizes GATA3 binding across the genome and modulates the response of breast cancer cells to estrogen signaling.

Keywords: Breast cancer, ChIP-seq, GATA3, Mutation, Transcription factor

\footnotetext{
* Correspondence: wadep2@niehs.nih.gov

'Laboratory of Molecular Carcinogenesis, National Institute of Environmental Health Sciences, 111 T.W. Alexander Dr, 27709 Research Triangle Park, NC, USA

Full list of author information is available at the end of the article
} 


\section{Background}

Accumulation of somatic mutations is responsible for development of breast cancer, as $85 \%$ of affected women have no family history of the disease (http://www.breastcancer. org). Nearly 31,000 point mutations and small insertions or deletions (indels) in at least 170 previously reported and novel cancer genes have been implicated in the development of breast tumors [1]. Whole exome sequencing places the zinc-finger transcription factor GATA3, with a $10 \%$ frequency of alterations, among the top three (together with p53 (TP53) and phosphoinositide-3-kinase $(P I K 3 C A))$ mutation driver genes in breast cancer $[1,2]$.

On the basis of mutation pattern, Vogelstein and colleagues [3] classify GATA3 as a tumor suppressor. Indeed, in mice xenograft studies GATA3 was positively correlated with survival and lack of metastasis [4]. However, it has been also postulated that GATA3 defines a distinct class of cancer genes that are differentiation factors rather than conventional tumor suppressor genes, which affect the malignant phenotype by enforcing differentiation [5-7]. Specifically, conditional deletion of GATA3 is not sufficient to promote malignant progression, and is not tolerated in early tumors [5,8]. GATA3 has been shown in mouse model of breast cancer to maintain tumor differentiation, suppress dissemination and inhibit metastasis $[8,9]$. While GATA3 has been intensively studied in the immune system, where it functions in development and differentiation of T-cells [10], it is also an essential regulator of mammary-gland morphogenesis and luminalcell differentiation $[11,12]$. It is frequently up-regulated in breast cancer and has been identified as a favorable prognosis marker [13]. GATA3 is involved in a positive cross-regulatory loop with estrogen receptor- $\alpha$ (ER $\alpha)$ [14] where they both serve as markers for luminal breast cancer $[15,16]$.

The interplay of GATA3, ER $\alpha$, and FOXA1 has been a topic of multiple functional genomic studies. Kong and co-authors defined an enhanceosome consisting of colocalizing ER $\alpha$-FOXA1-GATA3 which recruits RNA Pol II and p300 [17]. The triple conjoint binding sites are highly represented at the locations involved in frequent long-range chromatin interactions and associated with genes that are most responsive to estrogen. In turn, Theodorou and colleagues silenced GATA3 and observed a global redistribution of FOXA1 and p300 cofactors, and active histone marks prior to estrogen stimulation [18]. These global genomic changes alter the ER $\alpha$-binding profile that subsequently occurs following estrogen treatment, demonstrating that GATA3 can act upstream of FOXA1 in mediating ER $\alpha$ binding by modulating enhancer composition.

Haploinsufficiency of GATA3 in humans results in HDR syndrome, a rare condition inherited as autosomal dominant trait, characterized by hypoparathyroidism, deafness, and renal dysplasia [19]. Genomic alteration of GATA3 associated with HDR syndrome include large deletions removing the entire gene and flanking sequences, splice site mutations, indels, and point mutations resulting most often in frameshifts [20]. Mutations in HDR patients localized in the second zinc finger (ZnF2) of GATA3 or adjacent amino acids result in loss of DNA binding, whereas those in the first zinc finger ( $\mathrm{ZnF} 1)$ lead to loss of interaction with a cofactor, FOG2, or altered DNA-binding affinity [20,21]. Interestingly, while HDR GATA3 mutations are spread throughout the gene, breast cancer mutations cluster around $\mathrm{ZnF} 2$ and C-terminal domain [1,22,23]. Analysis of six different heterozygous GATA3 mutations from eight breast tumors has demonstrated loss or reduction of DNA binding ability, aberrant nuclear localization, decrease in transcription activation, and alterations in invasiveness, but not proliferation [22]. However, it is unclear how those functional modifications contribute to the oncogenesis process in breast cancer.

The aim of the present study was to evaluate the effect of a breast cancer-specific mutation in GATA3 on biochemical properties and genomic location of the protein. We utilized two luminal breast cancer cell lines, MCF7 harboring a heterozygous frameshift mutation in $\mathrm{ZnF} 2$, and T47D carrying wild-type version GATA3. We observed that mutant GATA3 was expressed at elevated levels relative to wild-type protein and it accumulated in nuclei. Surprisingly, the mutation led to enhanced protein stability following challenge with estrogen receptor agonist or antagonist. This increased stability led to increased levels, but not to global redistribution, of GATA3 binding in the genome as determined by ChIP-seq. The data collectively support the hypothesis that the carboxyl terminus of GATA3 contains protein regulatory information that ensures appropriate turnover following ligand binding by ER $\alpha$.

\section{Methods \\ Cell culture}

Human breast carcinoma cell lines MCF-7 and T47D were obtained from the American Type Culture Collection (Manassas, VA, USA) and cultured in DMEM/F-12 medium supplemented with $10 \% \mathrm{FBS}$ at $37^{\circ} \mathrm{C}$ in $5 \% \mathrm{CO}_{2}$. Protein stability was evaluated in the normal growth medium and cells were treated with $1 \mu \mathrm{M}$ cycloheximide (CHX) and/or $1 \mu \mathrm{M}$ MG132 (MG) for up to eight hours. For estrogen starvation assays, cells were grown for 72 hours in MEM medium containing 5\% FBS and then for 24 hours in phenol red-free MEM supplemented with $5 \%$ charcoal-dextran stripped FBS. Cells were treated with $50 \mathrm{nM} 17 \beta$-estradiol (E2) for 24 hours. The effect of ER $\alpha$ inhibitor, ICI 182,780 (ICI) was tested in normal growth medium. ICI was added at $100 \mathrm{nM}$ concentration and cells were harvested 24 hours later. MG (EMD Biosciences, 
San Diego, CA, USA) was dissolved in DMSO, CHX (Cayman Chemical, Ann Arbor, MI, USA) in water, ICI (Tocris Bioscience Ellisville, MS, USA) and E2 (Sigma, St. Louis, MO, USA) in ethanol.

\section{Subcellular fractionation}

Cells were grown in $10 \mathrm{~cm}$ tissue culture dishes until they were $70-80 \%$ confluent. The cells were washed with PBS, collected by scraping and resuspended in buffer containing $0.15 \mathrm{M} \mathrm{NaCl}, 10 \mathrm{mM}$ HEPES, pH 7.4, $1.5 \mathrm{mM} \mathrm{MgCl}$, $10 \mathrm{mM} \mathrm{KCl}, 0.5 \% \mathrm{NP}-40,0.5 \mathrm{mM}$ DTT and protease inhibitors. The cytoplasmic fraction was separated by centrifugation at $2500 \mathrm{rpm}$ for $10 \mathrm{~min}$. The pellet was resuspended in nuclear extraction buffer containing 0.1, $0.2,0.4$ or $0.8 \mathrm{M} \mathrm{NaCl}, 25 \mathrm{mM}$ HEPES, pH 7.4, $0.15 \mathrm{mM}$ spermidine, $0.5 \mathrm{mM}$ spermine, $5 \%$ glycerol, $1 \mathrm{mM}$ EDTA and protease inhibitors. Samples were rotated for $30 \mathrm{~min}$ at $+4^{\circ} \mathrm{C}$ and spun down in Optima Max centrifuge (Beckman Coulter, Brea, CA, USA) at 38,000 rpm for $45 \mathrm{~min}$ at $+4^{\circ} \mathrm{C}$. The nuclear fraction was collected and remaining pellet was dissolved in lysis buffer ( $8 \mathrm{M}$ urea, 1\% SDS, 0.125 M Tris, pH 6.8).

\section{Immunoblotting}

Whole cell lysates were obtained using $8 \mathrm{M}$ urea lysis buffer (8 M urea, 1\% SDS, $0.125 \mathrm{M}$ Tris, pH 6.8). Protein extracts $(15 \mu \mathrm{g})$ were resolved on SDS-PAGE gels and immunoblotted using the following antibodies: GATA3 (D13C9; Cell Signaling Technology, Danvers, MA), FOXA1 (ab23738; Abcam, Cambridge, MA, USA), ER $\alpha$ (sc-543; Santa Cruz Biotechnology, Santa Cruz, CA, USA) and actin (ab8226; Abcam). Signal intensity was analyzed using rectangular volume tool in Quantity One Analysis Software (Bio-Rad, Hercules, CA, USA) with global background subtraction.

\section{Immunofluorescence staining}

Cells were grown on glass coverslips in six-well tissue culture dishes. They were fixed with $4 \%$ formaldehyde in PBS for $10 \mathrm{~min}$, washed with PBS, and permeabilized with $0.1 \%$ Triton X-100 for 2 min, washed with PBS, and blocked with 5\% BSA in PBS. The coverslips were incubated with the anti-GATA3 antibody (Cell Signaling Technology) for one hour, washed with PBS, incubated with the secondary antibody (Alexa Fluor 568, Life Technologies, Grand Island, NY, USA) for one hour, washed with PBS, and mounted on glass slides with mounting medium containing 4',6-diamidino-2-phenylindole (DAPI). The slides were examined and photographed using a Zeiss Axiovert $200 \mathrm{M}$ microscope equipped with an Axiocam MR digital camera controlled by AxioVision software (Zeiss, Thornwood, NY, USA).

\section{Expression and purification of the DNA binding domain of GATA3}

DNA binding domain (DBD) of GATA3 (amino acids 261 to 371) was cloned into the pET-15b vector to produce a hexahistidine tagged fusion protein. The expression vector was transformed into the E.coli BL21 (DE3) CodonPlus RIL cells, and the cells were cultured at $37^{\circ} \mathrm{C}$. The bacterial cell lysate was centrifuged at $15,000 \mathrm{rpm}$ for $20 \mathrm{~min}$. The supernatant was mixed gently by the batch method with Ni-NTA beads (Qiagen, Valencia, CA, USA) at $+4^{\circ} \mathrm{C}$ for $30 \mathrm{~min}$. The beads were washed with $5 \mathrm{mM}$ imidazole-containing buffer and GATA3-DBD was eluted with $500 \mathrm{mM}$ imidazole-containing buffer. The fractions containing GATA3-DBD were subjected to MonoS column (GE Healthcare Life Sciences, Pittsburgh, PA, USA) chromatography. The binding domain was eluted with a 4-column volume linear gradient of $100-600 \mathrm{mM} \mathrm{NaCl}$. The protein was further purified by Superdex 75 column (GE Healthcare) in a buffer containing $20 \mathrm{mM}$ Tris- $\mathrm{HCl} \mathrm{pH}$ 7.5, $0.3 \mathrm{M} \mathrm{NaCl}, 10 \%$ glycerol, $2 \mathrm{mM} \mathrm{2-}$ mercaptoethanol, and $1 \mu \mathrm{M}$ zinc sulfate. For the purification of GATA3 mutant (D336fs) DBD, the Ni-NTA beads were washed with the $20 \mathrm{mM}$ imidazole-containing buffer. The fractions eluted from Ni-NTA beads were dialyzed against $20 \mathrm{mM}$ Tris- $\mathrm{HCl} \mathrm{pH}$ 7.5, $0.3 \mathrm{M} \mathrm{NaCl}, 10 \%$ glycerol, $2 \mathrm{mM} 2$-mercaptoethanol, and $1 \mu \mathrm{M}$ zinc sulfate buffer, and concentrated with Amicon ultra-centrifuge filter (Millipore, Billerica, MA, USA).

\section{Electrophoretic mobility shift assay (EMSA)}

GATA protein $(0.5,1,2$ or $4 \mu \mathrm{M}$ for the wild-type protein and $0.25,0.5,1$ or $2 \mu \mathrm{M}$ for the mutant protein) was incubated with $30 \mu \mathrm{M}$ of $20 \mathrm{bp}$ dsDNA (GATA3 recognition motif-containing oligonucleotide AATGTCCATCTGATA AGACG or GATA3 recognition motif-lacking oligonucleotide AATGTCAAACTTTTAAGACG) in $10 \mu \mathrm{l}$ of a reaction buffer $(28 \mathrm{mM}$ Tris $-\mathrm{HCl} \mathrm{pH} 7.5,1 \mathrm{mM}$ dithiothreitol, $0.8 \mathrm{mM}$ 2-mercaptoethanol, $120 \mathrm{mM} \mathrm{NaCl}$, $4 \%$ glycerol, and $0.4 \mu \mathrm{M}$ zinc sulfate). After $10 \mathrm{~min}$ incubation at $37^{\circ} \mathrm{C}$, the samples were analyzed by polyacrylamide gel electrophoresis, and the bands were visualized by ethidium bromide staining. In the competitive DNA binding assay, wild-type and mutated GATA3 DBDs were used individually or mixed in equimolar proportion. The reactions were performed with $15 \mu \mathrm{M}$ of 20 bp GATA3 motif-containing oligonucleotide and 23 bp GATA3 motiflacking DNA (CACTTTTTAACGTAATTTACTCT).

\section{Heparin chromatography}

T47D and MCF7 nuclear extracts were prepared as described above, using nuclear extraction buffer containing $0.4 \mathrm{M} \mathrm{NaCl}$. The extracts were applied to a $1 \mathrm{ml}$ HiTrap Heparin Sepharose (GE Healthcare Life Sciences). The column was eluted with a $10 \mathrm{ml}$ linear gradient of $\mathrm{NaCl}$ 
concentration from 0.1 to $1 \mathrm{M}$ in $20 \mathrm{mM}$ Hepes, pH 7.9 containing 20\% glycerol, $0.2 \mathrm{mM}$ EDTA, $0.1 \mathrm{mM}$ PMSF, and $0.5 \mathrm{mM}$ DTT. Separated fractions were analyzed by Western blot directed against anti-GATA3.

\section{Chromatin immunoprecipitation (ChIP) analysis}

GATA3 antibody was generated in rabbits using recombinant $6 \mathrm{x}$ histidine tag-fused GATA3 full-length wild-type protein. ChIP was performed as previously described [24] with the following modifications. T47D or MCF7 cells were cross-linked with 1\% formaldehyde in DMEM F12 for $10 \mathrm{~min}$ at room temperature, quenched with glycine, and then sonicated using Bioruptor (Diagenode, Liège, Belgium) to generate 200 to $400 \mathrm{bp}$ DNA fragments. Immunoprecipitation was performed with GATA3 serum, and normal rabbit serum (Santa Cruz Biotechnology, Dallas, TX, USA) was used as a control. The efficiency of the reaction was verified using SYBRgreen (Bio-Rad) based Real-Time PCR and primers developed by Eeckhoute et al. [14] for GATA3 binding sites at ESR1 locus. Quantitation of precipitated DNA was done using a standard curve with 10, 1, 0.1, and $0.01 \%$ of input DNA.

\section{ChIP-seq library construction}

DNA immunoprecipitated by GATA3 antibody in four to five individual reactions performed at the same time was pooled for T47D and MCF7 cells separately and purified using MinElute PCR Purification kit (Qiagen). Total $100 \mu \mathrm{g}$ of ChIP or input DNA, quantified with Qubit Fluorometer (Life Technologies, Grand Island, NY, USA) and dsDNA High Sensitivity Assay kit (Life Technologies), was used for library construction with the help of TruSeq RNA Sample Preparation kit (Illumina, San Diego, CA, USA). The library was prepared following the manufacturer's instructions, starting with the end repair step, and amplified with twelve PCR cycles. Two sets of libraries (ChIP and input) were prepared for each of the cell lines from samples immunoprecipitated on separate occasions. The libraries were sequenced on a Genome Analyzer IIx (Illumina) as single end 36mers.

\section{ChIP-seq data analysis}

To ensure that low quality reads were excluded from the analysis, the raw sequence reads were filtered to remove any entries with a mean base quality score $<20$. Filtered reads were aligned to the human genome (Genome Reference Consortium build 37/hg19; excluding haplotype chromosomes) via Bowtie (v0.12.8 with parameters $-\mathrm{m}$ 1 -v 2) [25]; only reads that were mapped to an unambiguous 'best' genomic location with no more than two mismatches were accepted. To limit PCR amplification bias, duplicate reads were removed using MarkDuplicates.jar from the Picard tools package (v1.62) (http:// picard.sourceforge.net). Replicate libraries were in good agreement and were merged prior to downstream analysis. All alignments were extended at the 3' end to a length of 180 bases (the average expected genomic fragment size for these libraries). 'bedGraph' files were generated from these uniquely-mapped, non-duplicated, extended reads for visualization of aggregate genomic coverage. Peak calling for regions of enriched GATA3 binding was performed with HOMER (v4.1; with default parameters and “-style factor -tbp 0 -inputtpb 0") [26] using input (unchipped) data to model background.

\section{Data release}

GATA3 ChIP-seq data have been deposited in NCBI's Gene Expression Omnibus [27] and are accessible through GEO Series accession number GSE51274 (http://www. ncbi.nlm.nih.gov/geo/query/acc.cgi?acc=GSE51274).

\section{Results}

Heterozygous mutation is present in GATA3 gene in MCF7 cell line

The human GATA3 gene consists of six exons, encoding a protein of 444 amino acids, which contains two transactivation domains (TA1 and TA2) and two zinc fingers (ZnF1 and ZnF2) (Figure 1A). This gene is frequently mutated in breast tumors. The luminal breast cancer cell line MCF7 carries a heterozygous insertion at position 1566, which leads to a frameshift (D336fs) in the second zinc finger and synthesis of a truncated GATA3 protein [23] (Figure 1B). We confirmed the presence of guanine insertion in GATA3 gene in our MCF7 stock and used a second luminal breast cancer cell line, T47D, wild-type for GATA3, as a control for our experiments. While T47D cells expressed only wild-type GATA3 protein (approximately $48 \mathrm{kDa}$ ), MCF7 cells contained both the full length GATA3 as well as a truncated protein of approximately $37 \mathrm{kDa}$ (Figure 1C). Steady state levels of this truncated protein in MCF7 cells were significantly higher than the full-length GATA3 in the same cells (Figure 1C).

\section{Truncated GATA3 protein is easily released from the nucleus}

We used T47D and MCF7 cell lines to study the effect of the frameshift mutation in GATA3 gene on the properties of the protein. Immunofluorescence staining was employed to verify cellular localization of GATA3 in T47D and MCF7 cells, demonstrating nuclear localization, regardless of the mutation status (Figure 2A). Subcellular fractionation with extraction buffer containing between 0.1 and $0.8 \mathrm{M} \mathrm{NaCl}$, demonstrated that wild-type GATA3 was extracted efficiently from nuclei at moderate salt concentration $(0.4 \mathrm{M} \mathrm{NaCl})$ from nuclei in T47D cells (Figure 2B). The full-length protein behaved in a similar manner in MCF7 cells and was released from nuclei at $0.4 \mathrm{M} \mathrm{NaCl}$. 


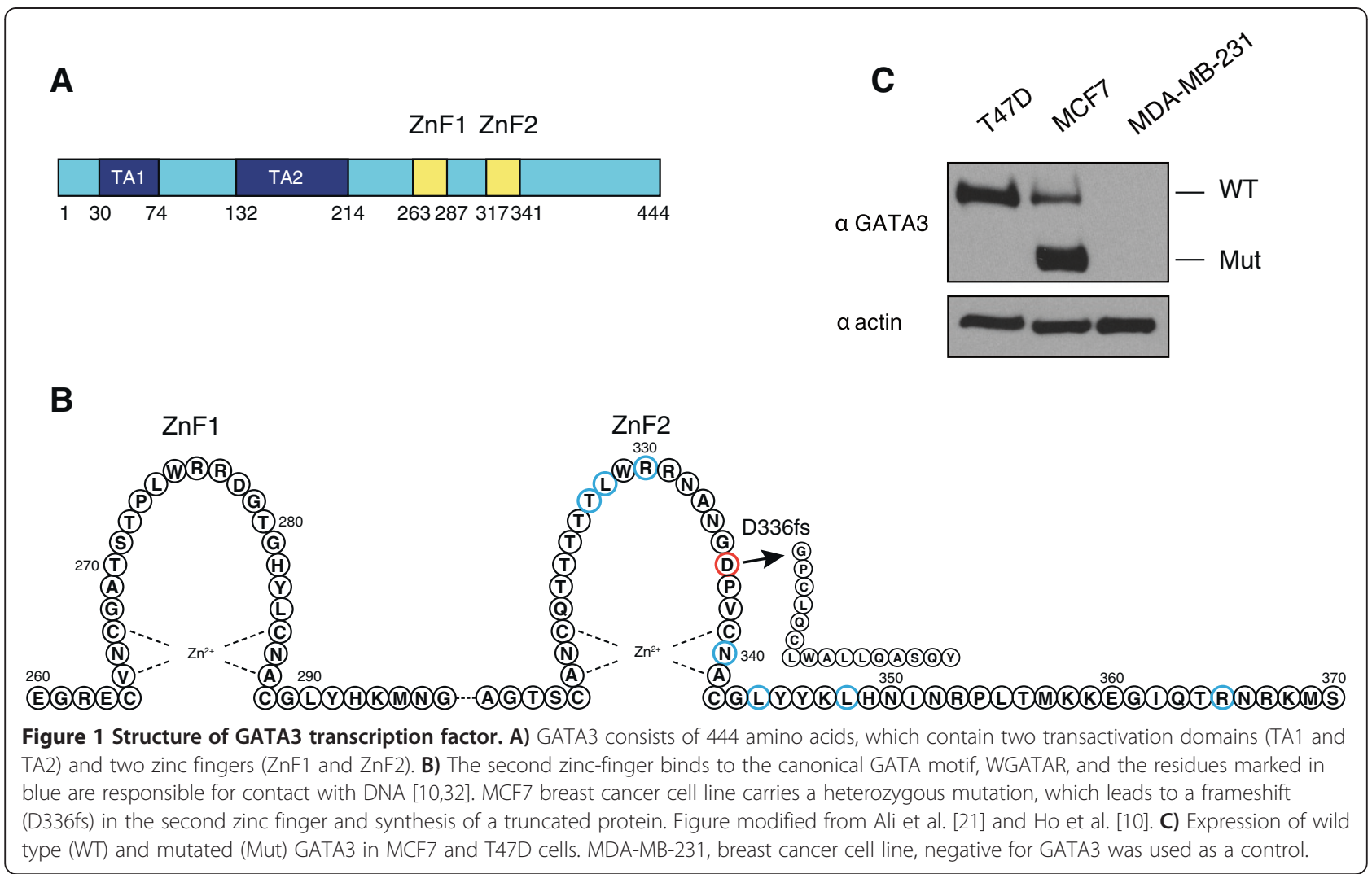

However, the truncated GATA3 was released from the chromatin with extraction buffer containing even the lowest $\mathrm{NaCl}$ concentration $(0.1 \mathrm{M})$. The truncation mutant was present in the cytoplasmic fraction as well, suggesting that a pool of mutant protein is nuclear, but has impaired interaction with chromatin and is easily released from the nucleus.

\section{The second-zinc finger frameshift mutation stabilizes GATA3 protein}

The increased steady-state abundance of the truncated GATA3 mutant in MCF7 (Figure 1C, also [23]) suggested that the mutation impacts stability. To test this hypothesis, T47D and MCF7 cells were treated with a translation inhibitor, cycloheximide and GATA3 abundance was measured over time using immunoblot of whole cell lysates. Over the course of eight hours, levels of wild-type GATA3 in T47D cells decreased, with a significant reduction visible four hours after the treatment (Figure 3A, Additional file 1: Figure S1). In contrast, both wild-type and mutant GATA3 in MCF7 exhibited greater stability, with half lives in excess of 8 hours (Figure 3A, Additional file 1: Figure S1), suggesting that the mutant protein titrates out a factor integral to GATA3 turnover.

Protein stability controlled by action of the $26 \mathrm{~S}$ proteasome is integral to the biology of ER $\alpha$ [28], which is found in close proximity to GATA3 at many genomic locations in breast cancer cells [17,18]. Inhibition of ubiquitin-proteasome pathway stabilizes GATA3 in developing T cells [29]. To determine whether GATA3 protein turnover is regulated in a similar, proteasome-dependent manner in breast cancer, we treated cells with cycloheximide and a proteasome inhibitor, MG132. In both T47D and MCF7 cells, proteasome inhibition alleviated the effect of translation inhibition on wild-type and, to a lesser degree, mutated GATA3 (Figure 3B). These data indicate that GATA3 is regulated at the protein level by the proteosome and that the cancer-specific mutation results in increased protein stability.

\section{GATA3 mutation uncouples turnover from the hormone response}

GATA3 is tied to ER $\alpha$ through a positive cross-regulatory loop [14] and ER $\alpha$ turnover by the proteosome is intimately connected to ligand binding [28]. As GATA3 protein stability was regulated in a manner similar to ER $\alpha$, we hypothesized that its stability might also be influenced by estradiol and that the frameshift mutation might impact protein-level regulation of GATA3 by hormone. Addition of estradiol to hormone starved cells results in cyclic variation of ER $\alpha$ levels, we chose a time point at which this cycling has stabilized (24 hours). Treating hormonestarved T47D or MCF7 cells with estradiol led to downregulation of ER $\alpha$, as expected (Figure 4A, B). GATA3 

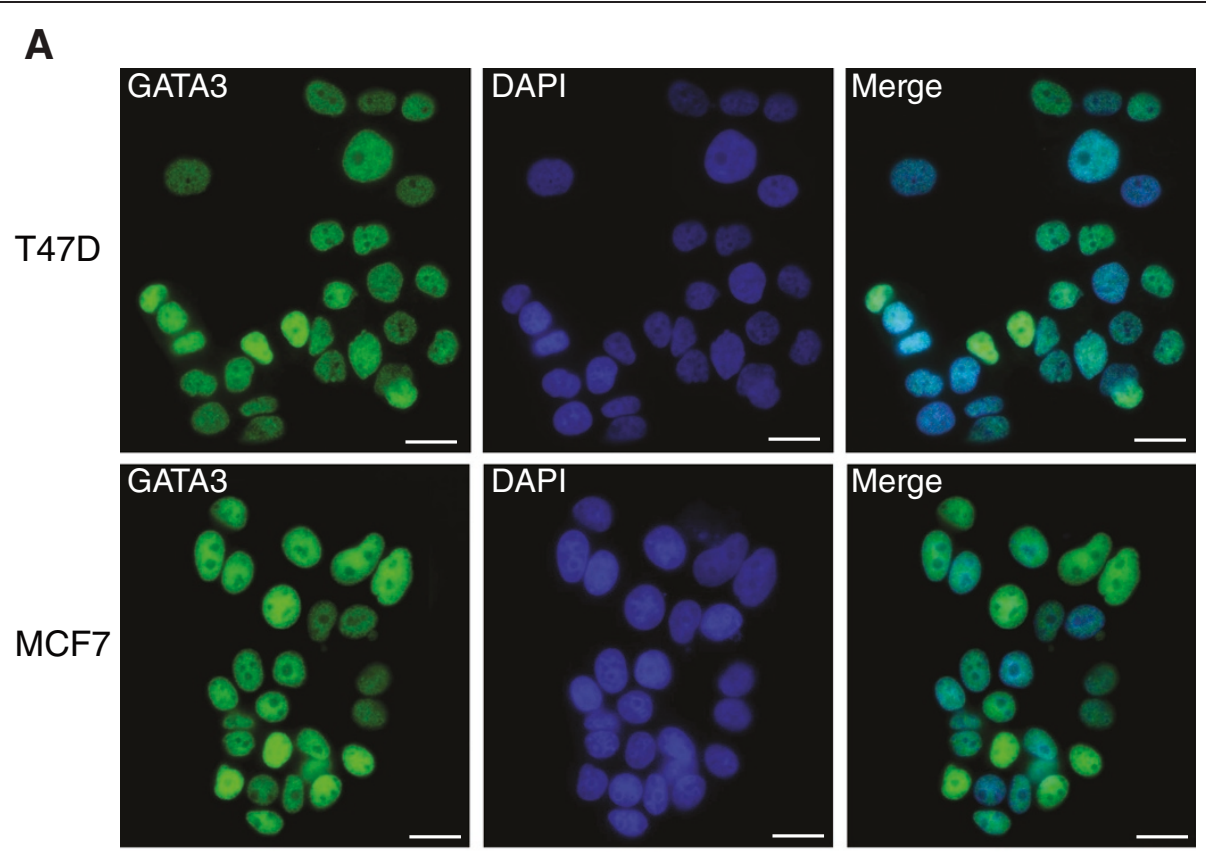

B
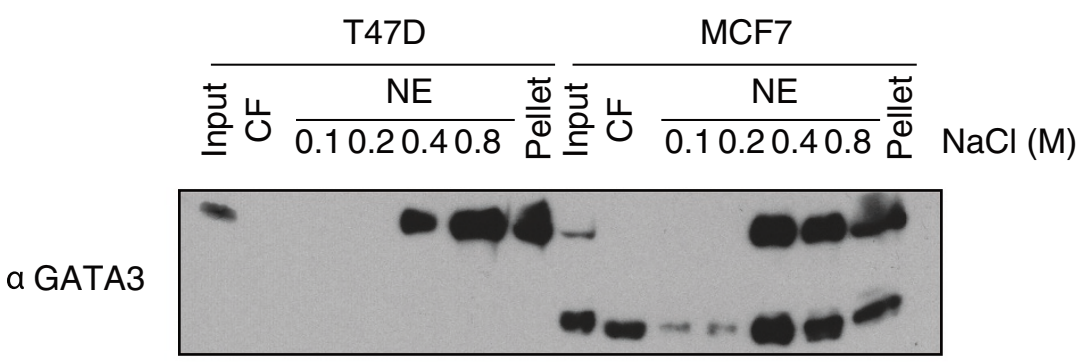

a actin

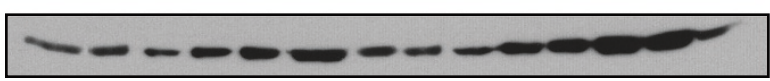

Figure 2 Cellular localization of wild-type and mutated GATA3 in breast cancer cells. A) Immunofluorescence staining of T47D and MCF7 cells. Scale bar corresponds to $20 \mu \mathrm{m}$. B) Subcellular fractionation of T47D or MCF7 cell extracts in 0.1-0.8 M NaCl. Input - whole cell lysate, CF - cytoplasmic fraction, NE - nuclear extract.

abundance in T47D cells was dramatically reduced by estradiol, mirroring ER $\alpha$. In contrast, both wild type and truncated GATA3 in MCF7 were only moderately affected by hormone. FOXA1, an essential determinant of ER $\alpha$ expression [30] and a frequent binding partner of ER $\alpha$ and GATA3 [17,31], decreased in abundance following estradiol treatment in T47D, although not to the same extent as GATA3 and ER $\alpha$ (Figure 4A, B). In MCF7, hormone had little to no impact on FOXA1 levels. These results suggest that the stability of three DNA binding transcription factors integral to the transcriptional response to estrogen in luminal breast cancer cells, exhibits altered turnover downstream of estrogen upon mutation of one allele of GATA3.

Because the truncating mutation alters GATA3 protein level following hormone treatment, we asked whether the action of estrogen antagonists was likewise affected by this mutation. We treated cells grown in normal conditions (media plus FBS) with the ER $\alpha$ antagonist, ICI 182,780 (ICI). As expected, ER $\alpha$ expression was reduced in both cell lines (Figure $4 \mathrm{C}$ ). While wild-type GATA3 protein levels were reduced following antagonist treatment in both T47D and MCF cells, the level of mutated GATA3 in MCF7 cells did not change. FOXA1 expression was not affected by ICI (Figure 4C). The GATA3 mRNA level remained mostly unaffected in cells treated with estradiol or ICI (Additional file 1: Figure S2). These experiments demonstrate that the truncation mutation in GATA3 stabilizes the protein in the face of agonist or antagonist binding by ER $\alpha$, thus uncoupling physiologic, protein-level regulation from estradiol action. 


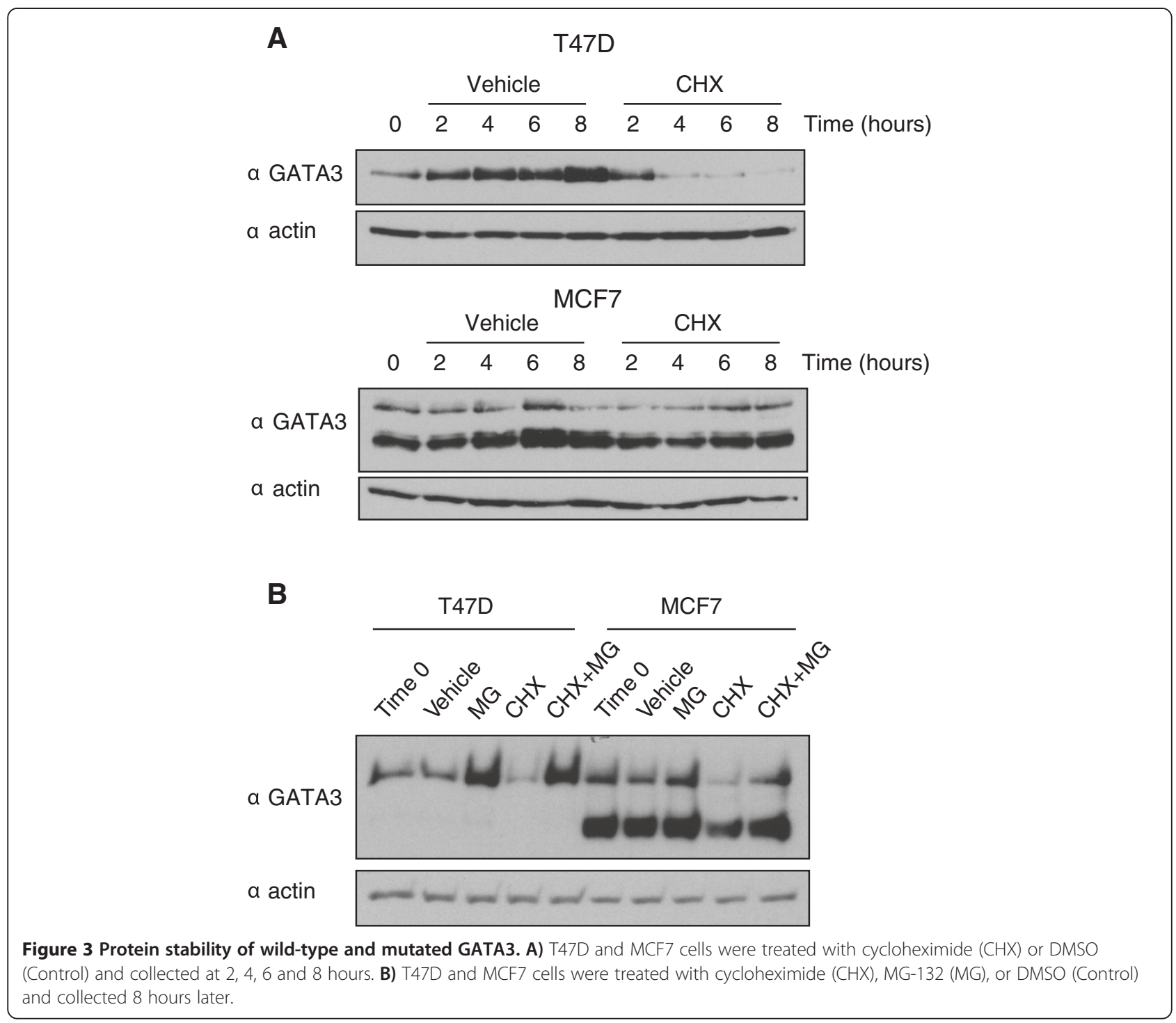

\section{DNA binding ability of mutated GATA3 is impaired}

The frameshift mutation present in GATA3 in MCF7 affects the second zinc finger, which is responsible for DNA binding [32]. We employed electrophoretic mobility shift assays (EMSA) to interrogate the DNA binding capacity of mutated GATA3 protein. By titrating the recombinant DNA binding domain (DBD) of wild-type GATA3 [32], we demonstrated a shift from the free GATA-motifcontaining oligonucleotide to a specific, protein bound complex (Figure 5A, lanes 1-5). In contrast, the mutant GATA3 DBD was able to bind DNA to a lesser degree and only at high concentrations of recombinant protein (Figure 5B, lanes 1-5). To assess whether the wild-type and mutant DBD protein fragments could heterodimerize on DNA, we mixed recombinant wild-type and mutated DBDs in a competitive assay with GATA motifcontaining and GATA motif-lacking oligonucleotide.
We did not observe any evidence of a complex with altered mobility following addition of mutant GATA3 DBD (Figure 5C, lanes 1-4 and 8-10). A similar experiment without competitor DNA had identical results (data not shown).

To further characterize the ability of endogenous GATA3 to bind DNA, we utilized heparin, a glycosaminoglycan structurally similar to nucleic acids. Nuclear extracts obtained from T47D and MCF7 cells were partially purified through ion exchange chromatography, applied to a heparin column, and eluted with a linear gradient of $\mathrm{NaCl}$. The peak of full-length GATA3 from T47D eluted between 0.57 and $0.71 \mathrm{M} \mathrm{NaCl}$ (Figure 6A). In MCF7 both fulllength and truncated GATA3 were eluted in the same range of salt, 0.51-0.63 M (Figure 6B), indicating a potential for formation of GATA3 wild-type/mutant heterodimers under these conditions. 


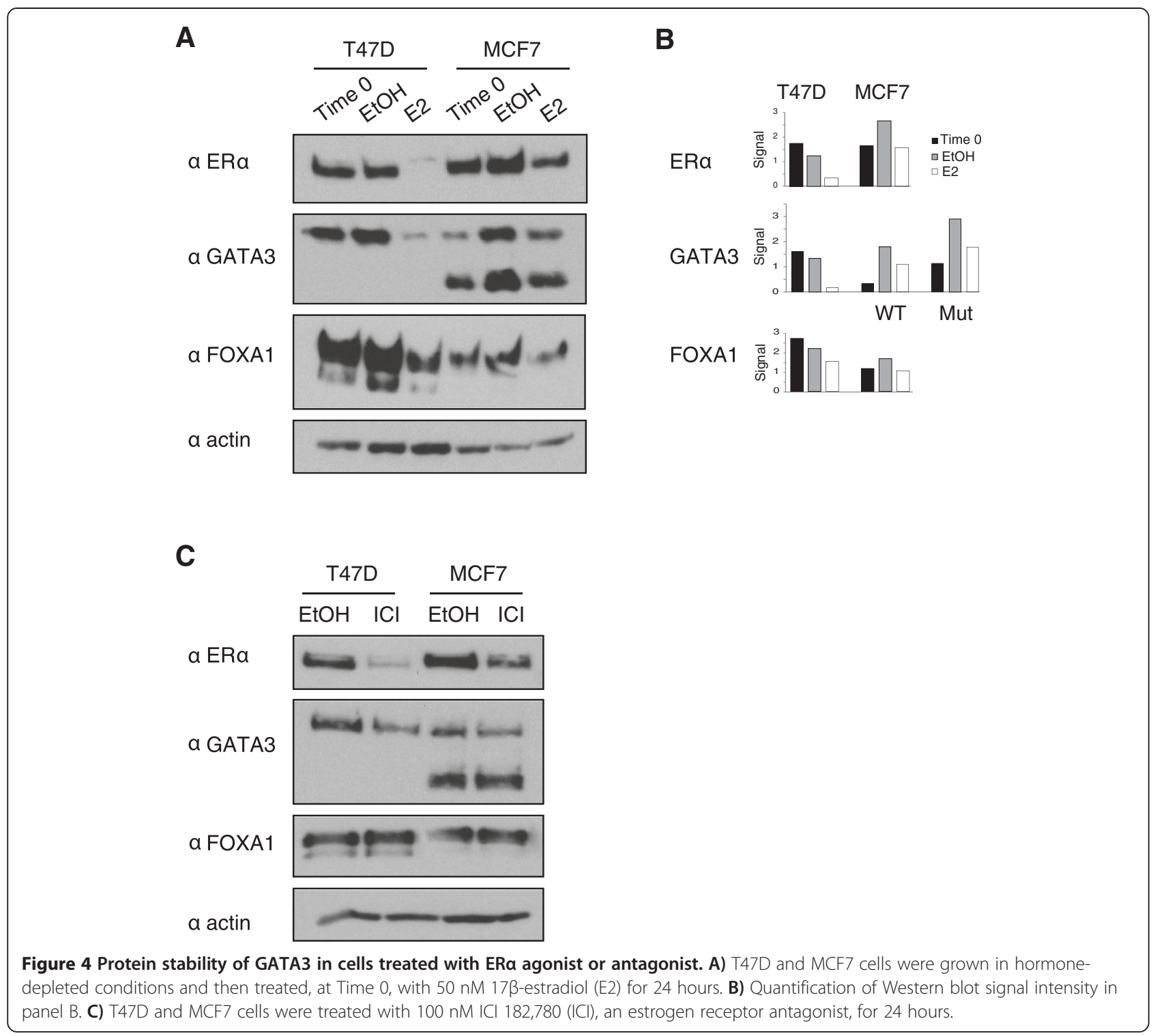

\section{Genomic location of GATA3 in breast cancer cells}

To analyze the genomic location of GATA3 transcription factor in T47D and MCF7 cells, we performed chromatin immunoprecipitation (ChIP) on asynchronous cultures. We first established a robust ChIP assay using polyclonal sera raised against full length recombinant GATA3 (which recognizes both full-length and mutant proteins). We assessed GATA3 enrichment at published positive control loci [14] using PCR for detection (Additional file 1: Figure S3). ChIP DNA was used to prepare standard libraries for massively parallel sequencing under conditions that preserve enrichment for the positive control regions (Additional file 1: Figure S4). Sequencing was performed on two biological replicates from T47D and MCF7 cells, resulting in $33-45 \times 10^{6}$ reads per library. Following quality control, mapping to unique positions in the human genome, and deduplication, 37-59\% reads were retained (Additional file 2: Table S1). Sequencing reads from the two libraries from each cell line were merged (Additional file 2: Table S2). The HOMER algorithm identified 11,593 enriched regions (peaks) in T47D cells and 21,173 in MCF7 cells. Total 6,336 of these peaks overlapped by at least $1 \mathrm{bp}$ (Figure 7A). Selected ChIP-seq peaks were validated using Real-Time PCR (Additional file 1: Figure S5).

We explored the similarities in ChIP-seq between the two cell lines in terms of location relative to genomic features and intensity. In spite of the difference in number of GATA3 enriched regions, peak distribution relative to the closest transcription start site (TSS) was similar in T47D and MCF7 cells (Figure 7B). T47D cells had modestly higher frequency of enrichment in the range from $-1 \mathrm{~kb}$ 
A

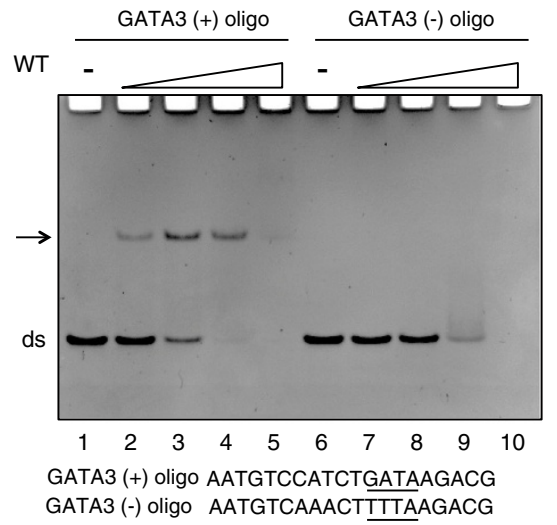

C

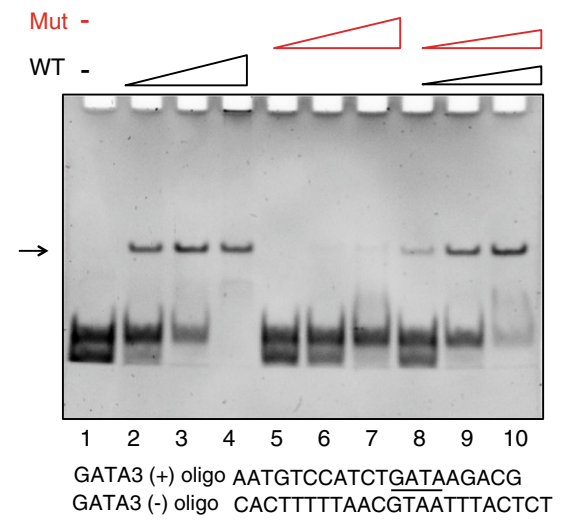

B

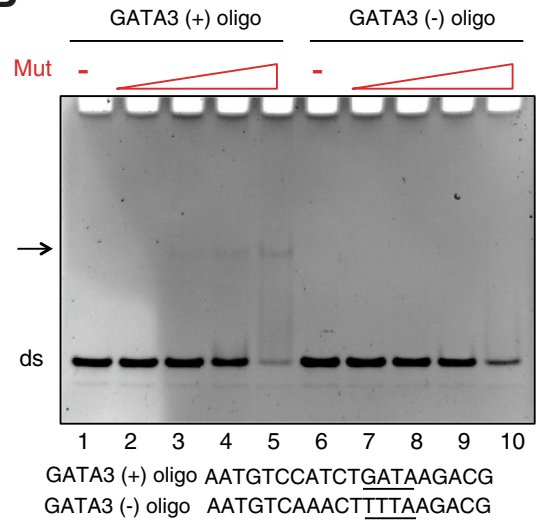

Figure 5 DNA binding ability of wild-type and mutated GATA3. Electrophoretic Mobility Shift Assay (EMSA) was performed using recombinant $\mathbf{A}$ ) wild-type GATA3 DNA binding domain (DBD) or B) mutated GATA3-DBD. Equivalent molar amounts of wild-type and mutant protein, assessed by Coomassie blue stained SDS-PAGE, were used. C) In a competitive assay, an equimolar mix of wild-type and mutated DBD proteins was used. To test protein ability to bind DNA, GATA3 motif-containing oligonucleotides (GATA +) and GATA3 motif-lacking oligonucleotides (GATA-) were used. WT - wild-type, Mut - mutated GATA3.

to $+2 \mathrm{~kb}$ from TSS (Figure $7 \mathrm{C}, \mathrm{D}$ ). When the peaks were sorted by ChIP-seq signal, distribution in both cell lines was almost indistinguishable for peaks within $10 \mathrm{~kb}$ from the closest TSS as well as for those not associated with TSS - meaning that high-intensity peaks were distributed in a similar manner (Figure 7E). While these general indicators of pattern of enrichment appeared highly similar across the two cell lines, we observed a difference in overall signal intensity at peaks. Regardless of their localization relative to TSSs, bins of peaks in MCF7 exhibited a broader range of signal intensity than comparable bins in T47D (Figure 7F). This relationship was further corroborated by scrutiny of mean and median values for peaks grouped according to distance from TSS, where MCF7 invariably had higher mean and median values. At a gross level, the overall pattern of association of GATA3 with the genome appeared highly similar between the two cell lines. However, peak signal intensity after normalization for read depth was higher in MCF7 than in T47D.
Assigning GATA3 peaks to the closest transcription start site (TSS) resulted in 4524 genes within $50 \mathrm{~kb}$ in T47D and 6934 in MCF7, including 3011 genes overlapping between both cell lines (Table 1, Additional file 3: Tables S3 and S4). Ingenuity Pathway Analysis of genes associated with genomic regions enriched for GATA3 binding indicated that cell cycle, death and survival, growth and proliferation, movement, and development were the top functional categories related to GATA3 presence in T47D cells (Additional file 1: Figure S6). The top molecular and cellular functions in MCF7 were similar and included cellular growth and proliferation, development, movement, death and survival, and cell to cell signaling and interaction (Additional file 1: Figure S7). A more detailed analysis focusing on genes involved in mammary tissue differentiation, breast cancer subtype determination, or estrogen response [31,33-35], showed that although GATA3 was present near $20-60 \%$ of TSSs, there was no enrichment detected when compared to the expected occupancy in a given functional group. Also, there 
A

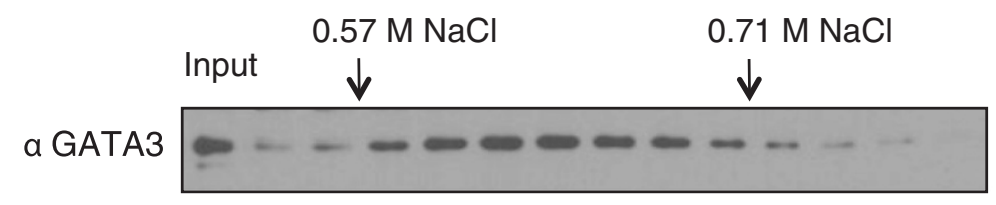

B

MCF7

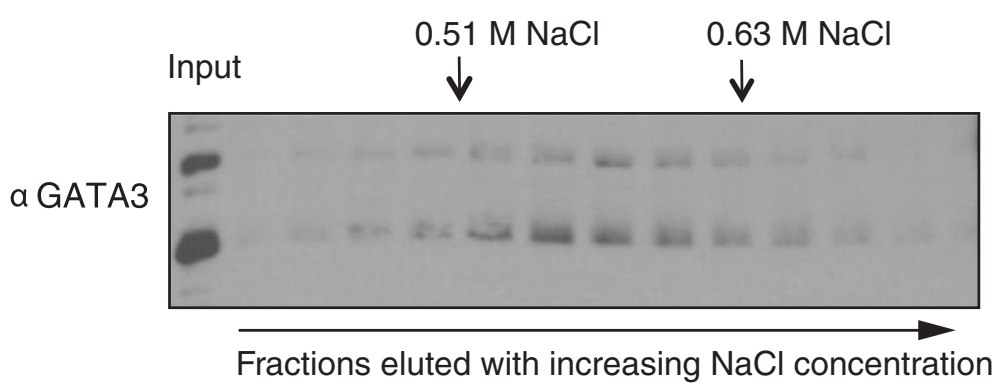

Figure 6 Biochemical characterization of wild-type and mutant GATA3 using a nucleic acid analog. Nuclear extracts were prepared from A) T47D and B) MCF7 cells and applied to heparin sepharose. The column was eluted with linear gradient of NaCl concentration from 0.1 to 1 M. The separated fractions were analyzed by Western blot directed against GATA3.

were no major differences in the tested datasets between GATA3 transcription factor binding in T47D and MCF7 cells (Additional file 1: Figures S8-S10).

There were, however, individual genes that differed substantially in GATA3 enrichment between cell lines (Additional file 4: Table S5). The progesterone receptor (PGR) is an example of an individual locus displaying a difference in GATA3 occupancy between cell lines, with T47D featuring seven peaks spanning over $200 \mathrm{~kb}$ and MCF7 cells containing only one peak in the same region (Figure 8). The biologic significance of this finding remains unclear, although the reduced expression of PGR in MCF7, as compared to T47D, may be reflective of alterations in GATA3 binding (Additional file 1: Figure S11).

Using a mobility shift assay, we established that the frameshift mutation present in GATA3 in MCF7 impairs the protein's ability to bind DNA. To test whether the mutation affects the capacity to specifically recognize DNA sequence in the genome, we evaluated the frequency of occurrence of the GATA3 canonic recognition motif, WGATAR within the ChIP-seq peaks. The proportion of GATA3 peaks containing the recognition motif in T47D and MCF7 cells was essentially identical - 71.4\% and $72.7 \%$, respectively (Table 2 ). We explored whether binning peaks in several different ways impacted this similarity and found that no matter how we grouped the peaks, the frequency of peaks containing the consensus GATA3 element was consistent between the two cell lines (Additional file 1: Figure S12). These data suggest that the mutation in MCF7 does not significantly change the binding site preference of GATA3 in the context of chromatin.

\section{Discussion}

Large-scale genome sequencing projects have provided, and continue to provide, volumes of information on the mutational landscape of cancers. A current challenge for cancer biologists is to investigate the emerging genomic data in a mechanistic context, establishing the relationship of specific mutations to tumor biology and informing on clinical parameters including aggressiveness, response to therapy, and potential for metastasis. Here, we have initiated an attempt to address the mechanistic basis by which mutations in the transcription factor GATA3 may provide a growth advantage to breast cancer cells. The Cancer Genome Atlas Network (TCGA) recently reported a comprehensive study of human breast cancer: tumors from 507 patients were analyzed on multiple high information content platforms: whole exome sequencing, DNA copy number arrays, DNA methylation, mRNA array and sequencing, microRNA sequencing and reverse-phase protein arrays [1]. Somatic mutations in GATA3 occurred in 58 cases $(10.7 \%)$, predominantly in luminal A and B cancer subtypes, an additional 12 samples displayed copy number alterations (http://www.cbioportal.org). Strikingly, while mutations of GATA3 in the congenital disorder HDR syndrome are found throughout the protein [22], breast cancer specific mutations occur almost exclusively in exons 5 and 6 (TCGA). This clustering suggests 


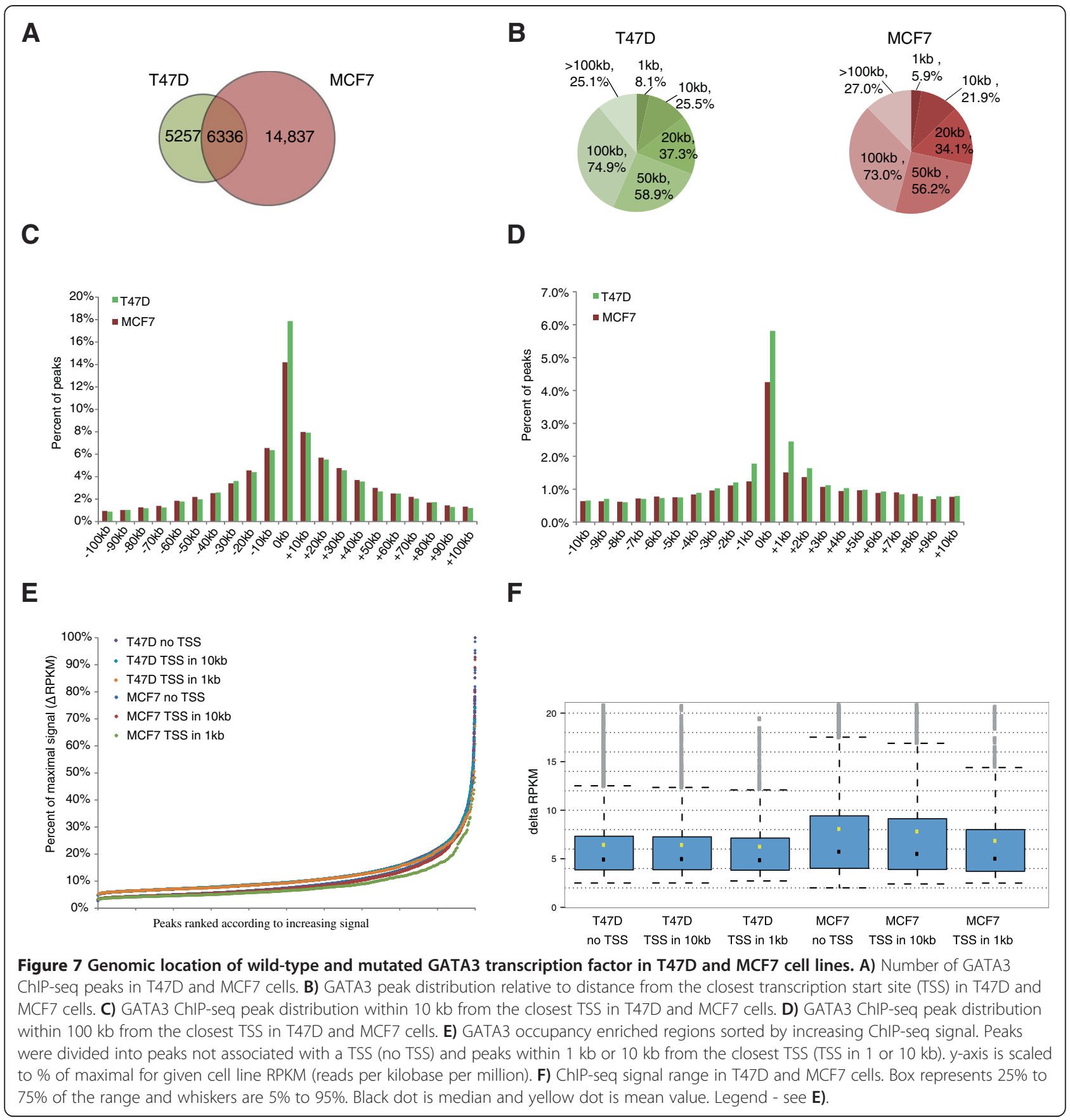

regulatory roles for the carboxyl terminus of GATA3 and that impairment of these functions can provide a growth advantage to cancer cells.

Careful scrutiny of the TCGA mutation data revealed that six mutations were localized in the second zinc finger and five of them were frameshifts, similar to the mutation in MCF7 [23], making MCF7 a useful model to study a clinically relevant phenomenon. We confirmed the presence of a heterozygous guanine insertion in the fifth exon of GATA3 in the MCF7 genome and showed that although both full-length and truncated proteins were expressed, the mutated protein was present in the cells at a higher level. The D336 frameshift does not affect the $\mathrm{N}$-terminal and $\mathrm{C}$-terminal sequences flanking $\mathrm{ZnF} 1$ that are required for nuclear localization [22] and GATA3 proteins localized to the nucleus of MCF7 cells. Mutations in GATA3 ZnF2 impair DNA binding [20-22] suggesting that the same effect could be expected for MCF7-specific mutation. The biochemical fractionation assay identified a pool of truncated protein very loosely 
Table 1 Number of genes associated with GATA3 transcription factor binding in T47D and MC7 breast cancer cell lines within $\mathbf{1 0}$ and $\mathbf{5 0} \mathbf{~ k b}$ from the closest transcription start site (TSS)

\begin{tabular}{|c|c|c|}
\hline \multirow[t]{2}{*}{ Cell line } & \multicolumn{2}{|c|}{ Number of genes ${ }^{*}$} \\
\hline & $+/-10$ kb from TSS & $+/-50 \mathrm{~kb}$ from TSS \\
\hline T47D & 2433 & 4524 \\
\hline MCF7 & 3592 & 6934 \\
\hline Common & 1649 & 3011 \\
\hline
\end{tabular}

"Genes may contain more than one GATA3 peak within specified distance from TSS.

associated with chromatin (Figure 2B). However, the gel shift assay demonstrated that truncated GATA3 could bind DNA selectively, albeit with decreased affinity compared to wild-type (Figure 5). Consistent with the documented capacity of GATA3 to self-associate and to dimerize on DNA [32], we observed a pool of mutant protein that exhibited similar chromatin binding properties to wild-type GATA3. The data are consistent with formation of heterodimers between mutant and wildtype GATA3, potentially altering the association of the protein with its recognition elements in the genome.

ChIP-seq was utilized to assess the degree of overlap of GATA3 across the two cell lines used in our study. Surprisingly, the number of binding sites detected in MCF7 was substantially higher than in T47D cells. In spite of the large difference in genomic occupancy, detailed analysis of genes associated with GATA3 binding failed to identify any major functional differences between binding profiles in T47D and MCF7 cell lines (Additional file 1: Figure S6-S10). We speculated that the increased number of GATA3-enriched regions in MCF7 genome could have been due to compromised ability of the truncated protein to recognize the specific GATA binding motif, WGATAR. However, the proportion of GATA3 peaks containing the WGATAR motif was nearly identical in binding regions identified in T47D and MCF7 cells, as well as in cell-line specific regions (Table 2). This finding suggested that the heterozygous mutation did not affect binding specificity in MCF7 cells.

Although the number of GATA3 peaks was considerably lower in T47D than in MCF7 cells, progesterone receptor gene was an example of a locus featuring a greater number of bound regions in T47D than in MCF7. Remarkably, lack of PGR expression, as determined by immunohistochemical staining, was a common denominator for all five patients in the TCGA database carrying a frameshift mutation in ZnF2 of GATA3 (http://www.cbioportal.org). Even though both T47D and MCF7 cell lines are classified as PGR and ER $\alpha$ positive, and belong to luminal A breast cancer subtype [36], MCF7 has been also used as a model for luminal B subtype [37]. The luminal B subtype is the more aggressive form of ER $\alpha$-positive breast cancer that is less responsive to endocrine therapy [38]. It is characterized by increased expression of proliferation-related genes and lower expression of ER-dependent genes, including PGR [38,39]. In our model system, PGR mRNA level was approximately 20-fold lower in MCF7 than in T47D cells (Additional file 1: Figure S11). Loss of PGR expression is often considered as a marker for the gain of hormoneindependent growth properties by ER $\alpha$-positive breast cancers, through increased cross-talk between ER $\alpha$ and growth factor signaling pathways [38,40]. In addition, the normal balance of the two known PGR isoforms, A or B, impacts biological properties of tumors [41].

Comparison of the biochemical properties of mutated GATA3 with wild type protein present in the T47D cell line demonstrated an increased half-life of truncated GATA3 in normal growth conditions and in response to ER $\alpha$ agonist and antagonist (Figures 3 and 4). GATA3 levels were proteasome-dependent (Figure 3B), similar to

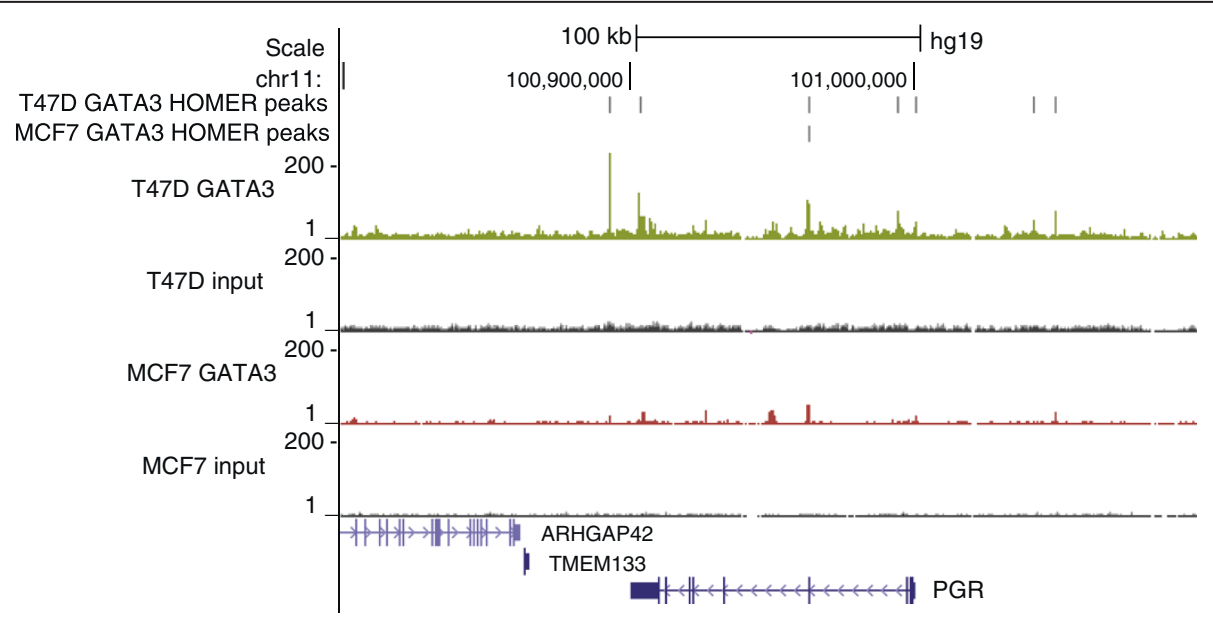

Figure 8 Transcription factor GATA3 binding at progesterone receptor (PGR) locus in T47D and MC7 cells. 
Table 2 Frequency of GATA3 recognition motif WGATAR in GATA3-peaks identified by ChIP-seq in T47D and MCF7 cells

\begin{tabular}{lccc}
\hline GATA3 peaks & All & \multicolumn{2}{c}{$\begin{array}{c}\text { Peaks containing } \\
\text { WGATAR motif }\end{array}$} \\
\cline { 3 - 4 } & & Number & Percent [\%] \\
\hline T47D & 11593 & 8281 & 71.4 \\
T47D peaks overlapping with MCF7 & 6336 & 4655 & 73.5 \\
T47D-specific & 5257 & 3626 & 69.0 \\
MCF7 & 21173 & 15392 & 72.7 \\
MCF7 peaks overlapping with T47D & 6336 & 4590 & 72.4 \\
MCF7-specific & 14837 & 10802 & 72.8 \\
\hline
\end{tabular}

$\mathrm{ER} \alpha$, where rapid turnover of the receptor upon ligand binding is based on the ubiquitin-proteasome pathway [28]. GATA3 is required for estrogen stimulation of cell cycle progression in breast cancer cells [14] and we showed that this truncating mutation present in MCF7 genome uncouples protein level regulation from hormonal signaling.

\section{Conclusions}

These findings strongly suggest that the carboxyl terminus of GATA3, a mutational hotspot in breast cancer, confers regulation on protein levels through as yet undefined mechanisms, resulting in increased stability of transcription factors resident on critical response elements in the breast cancer genome. We predict that mutations in GATA3 with similar characteristics to the mutation in MCF7 likely confer a growth advantage, particularly in pre-menopausal women, and are likely to occur early in tumor evolution.

\section{Additional files}

Additional file 1: Figure S1. Quantification of Western blot signal intensity for full-length and truncated GATA3 protein in T47D and MCF7 cells treated with DMSO (Vehicle) or cycloheximide (CHX) over the course of eight hours. Figure S2. GATA3 mRNA level in T47D and MCF7 cells treated with estradiol (E2) or ICI 182,780 (ICI). Figure S3. GATA3 enrichment determined by Real-Time PCR in ChIP reactions pooled for ChIP-seq library preparation. Figure S4. GATA3 enrichment in PCR-amplified ChIP-seq library in positive (ESR1 Enh1) and negative (ESR1 -6.9 kb) control regions located upstream from estrogen receptor transcription start. Figure S5. Real-Time PCR validation of GATA3 binding in T47D and MCF7 genome determined by ChIP-seq. Figure S6.

Functional classification of genes located within $50 \mathrm{~kb}$ from a GATA3 ChIP-seq peak in T47D cells. Figure S7. Functional classification of genes located within $50 \mathrm{~kb}$ from a GATA3 ChIP-seq peak in MCF7 cells. Figure S8. GATA3 ChIP-seq peak presence in T47D and MCF7 cells within $10 \mathrm{~kb}$ from TSS of genes involved in normal mammary cell commitment and differentiation. Figure S9. GATA3 ChIP-seq peak presence in T47D and MCF7 cells within $50 \mathrm{~kb}$ from TSS of estrogen-responsive genes. Figure S10. GATA3 ChIP-seq peak presence in T47D and MCF7 cells within $50 \mathrm{~kb}$ from TSS of genes differentially expressed in different molecular subtypes of breast cancer. Figure S11. Progesterone receptor (PGR) expression in T47D and MCF7 cells treated with GATA3 siRNA (Error bars represent standard deviation; $n=2$ ) or infected with GATA3 adenovirus
(Adv) $(n=1)$. Figure $\mathbf{S} 12$. Frequency of GATA3 recognition motif, WGATAR, in GATA3 ChIP-seq peaks located within $10 \mathrm{~kb}$.

Additional file 2: Table S1. Number of reads in each sequencing run for GATA3 ChIP-seq in T47D and MCF7 cell lines. Table S2. Number of reads in merged samples for two replicates of GATA3 ChIP-seq in T47D and MCF7 cell lines.

Additional file 3: Table S3. GATA3 ChIP-seq peaks identified in T47D cell line. Peaks overlapping with MCF7 by at least 1 bp are indicated, as well as the nearest gene to the peak, within $10 \mathrm{~kb}$ or $50 \mathrm{~kb}$ from peak border. Table S4. GATA3 ChIP-seq peaks identified in MCF7 cell line. Peaks overlapping with T47D by at least $1 \mathrm{bp}$ are indicated, as well as the nearest gene to the peak, within $10 \mathrm{~kb}$ or $50 \mathrm{~kb}$ from peak border.

Additional file 4: Table S5. Genes with GATA3 ChIP-seq peak within $10 \mathrm{~kb}$ from transcription start site (TSS).

\section{Competing interest}

The authors declare no competing interest.

\section{Authors' contribution}

Experimental design - ABA, MT, JKS, PAW. Performed experiments - ABA, $C M, M T$, JKS. Data analysis - SAG, ABA, PAW. Manuscript preparation - all authors. All authors read and approved the final manuscript.

\section{Acknowledgements}

This research was supported by the Intramural Research Program of the $\mathrm{NIH}$, National Institute of Environmental Health Sciences.

\section{Author details}

'Laboratory of Molecular Carcinogenesis, National Institute of Environmental Health Sciences, 111 T.W. Alexander Dr, 27709 Research Triangle Park, NC, USA. ${ }^{2}$ Division of Intramural Research, National Institute of Environmental Health Sciences (NIEHS), Research Triangle Park, NC, USA.

Received: 7 November 2013 Accepted: 3 April 2014 Published: 22 April 2014

\section{References}

1. Koboldt DC, Fulton RS, McLellan MD, Schmidt H, Kalicki-Veizer J, McMichael JF, Fulton LL, Dooling DJ, Ding L, Mardis ER, Wilson RK, Ally A, Balasundaram M, Butterfield YSN, Carlsen R, Carter C, Chu A, Chuah E, Chun HJE, Coope RJN, Dhalla N, Guin R, Hirst C, Hirst M, Holt RA, Lee D, Li HYl, Mayo M, Moore RA, Mungall AJ: Comprehensive molecular portraits of human breast tumours. Nature 2012, 490:61-70.

2. Stephens PJ, Tarpey PS, Davies H, Van Loo P, Greenman C, Wedge DC, Nik-Zainal S, Martin S, Varela I, Bignell GR, Yates LR, Papaemmanuil E, Beare D, Butler A, Cheverton A, Gamble J, Hinton J, Jia MM, Jayakumar A, Jones D, Latimer C, Lau KW, McLaren S, McBride DJ, Menzies A, Mudie L, Raine K, Rad R, Chapman MS, Teague J: The landscape of cancer genes and mutational processes in breast cancer. Nature 2012, 486:400-404.

3. Vogelstein B, Papadopoulos N, Velculescu VE, Zhou SB, Diaz LA, Kinzler KW: Cancer genome landscapes. Science 2013, 339:1546-1558.

4. Yan W, Cao QJ, Arenas RB, Bentley B, Shao R: GATA3 inhibits breast cancer metastasis through the reversal of epithelial-mesenchymal transition. J Biol Chem 2010, 285:14042-14051.

5. Chou J, Provot S, Werb Z: GATA3 in development and cancer differentiation: cells GATA have it! I Cell Physiol 2010, 222:42-49.

6. Zheng R, Blobel GA: GATA transcription factors and cancer. Genes Cancer 2010, 1:1178-1188

7. Chou J, Lin JH, Brenot A, Kim JW, Provot S, Werb Z: GATA3 suppresses metastasis and modulates the tumour microenvironment by regulating microRNA-29b expression. Nat Cell Biol 2013, 15:201-213.

8. Kouros-Mehr H, Bechis SK, Slorach EM, Littlepage LE, Egeblad M, Ewald AJ, Pai SY, Ho IC, Werb Z: GATA-3 links tumor differentiation and dissemination in a luminal breast cancer model. Cancer Cell 2008, 13:141-152.

9. Dydensborg AB, Rose AAN, Wilson BJ, Grote D, Paquet M, Giguere V, Siegel PM, Bouchard M: GATA3 inhibits breast cancer growth and pulmonary breast cancer metastasis. Oncogene 2009, 28:2634-2642. 
10. Ho IC, Tai T-S, Pai S-Y: GATA3 and the T-cell lineage: essential functions before and after T-helper-2-cell differentiation. Nat Rev Immunol 2009, 9:125-135.

11. Asselin-Labat ML, Sutherland KD, Barker H, Thomas R, Shackleton M, Forrest NC, Hartley L, Robb L, Grosveld FG, van der Wees J, Deb S, Fox SB, Smyth GK, Lindeman GJ, Visvader JE: Gata-3 is an essential regulator of mammary-gland morphogenesis and luminal-cell differentiation. Nat Cell Biol 2007, 9:201-209.

12. Kouros-Mehr H, Slorach EM, Sternlicht MD, Werb Z: GATA-3 maintains the differentiation of the luminal cell fate in the mammary gland. Cell 2006, 127:1041-1055.

13. Mehra R, Varambally S, Ding L, Shen R, Sabel MS, Ghosh D, Chinnaiyan AM, Kleer CG: Identification of GATA3 as a breast cancer prognostic marker by global gene expression meta-analysis. Cancer Res 2005, 65:11259-11264.

14. Eeckhoute J, Keeton EK, Lupien M, Krum SA, Carroll JS, Brown M: Positive Cross-Regulatory Loop Ties GATA-3 to Estrogen Receptor a Expression in Breast Cancer. Cancer Res 2007, 67:6477-6483.

15. Oh DS, Troester MA, Usary J, Hu Z, He X, Fan C, Wu J, Carey LA, Perou CM: Estrogen-regulated genes predict survival in hormone receptor-positive breast cancers. J Clin Oncol 2006, 24:1656-1664.

16. Sørlie T, Tibshirani R, Parker J, Hastie T, Marron JS, Nobel A, Deng S, Johnsen H, Pesich R, Geisler S, Demeter J, Perou CM, Lønning PE, Brown PO, Børresen-Dale A-L, Botstein D: Repeated observation of breast tumor subtypes in independent gene expression data sets. Proc Natl Acad SCl USA 2003, 100:8418-8423.

17. Kong SL, Li G, Loh SL, Sung WK, Liu ET: Cellular reprogramming by the conjoint action of ERalpha, FOXA1, and GATA3 to a ligand-inducible growth state. Mol Syst Biol 2011, 7:526.

18. Theodorou V, Stark R, Menon S, Carroll JS: GATA3 acts upstream of FOXA1 in mediating ESR1 binding by shaping enhancer accessibility. Genome Res 2013, 23:12-22.

19. Van Esch $H$, Groenen $P$, Nesbit MA, Schuffenhauer S, Lichtner $P$, Vanderlinden $G$, Harding B, Beetz R, Bilous RW, Holdaway I, Shaw NJ, Fryns J-P, Van de Ven W, Thakker RV, Devriendt K: GATA3 haplo-insufficiency causes human HDR syndrome. Nature 2000, 406:419-422.

20. Nesbit MA, Bowl MR, Harding B, Ali A, Ayala A, Crowe C, Dobbie A, Hampson G, Holdaway I, Levine MA, McWilliams R, Rigden S, Sampson J, Williams AJ, Thakker RV: Characterization of GATA3 mutations in the hypoparathyroidism, deafness, and renal dysplasia (HDR) syndrome. J Biol Chem 2004, 279:22624-22634.

21. Ali A, Christie PT, Grigorieva IV, Harding B, Van Esch H, Ahmed SF, Bitner-Glindzicz M, Blind E, Bloch C, Christin P, Clayton P, Gecz J, Gilbert-Dussardier B, Guillen-Navarro E, Hackett A, Halac I, Hendy GN, Lalloo F, Mache CJ, Mughal Z, Ong AC, Rinat C, Shaw N, Smithson SF, Tolmie J, Weill J, Nesbit MA, Thakker RV: Functional characterization of GATA3 mutations causing the hypoparathyroidism-deafness-renal (HDR) dysplasia syndrome: insight into mechanisms of DNA binding by the GATA3 transcription factor. Hum Mol Genet 2007, 16:265-275.

22. Gaynor KU, Grigorieva IV, Allen MD, Esapa CT, Head RA, Gopinath P, Christie PT, Nesbit MA, Jones JL, Thakker RV: GATA3 mutations found in breast cancers may be associated with aberrant nuclear localization, reduced transactivation and cell invasiveness. Horm Canc 2013, 4:123-139.

23. Usary J, Llaca V, Karaca G, Presswala S, Karaca M, He X, Langerod A, Karesen R, Oh DS, Dressler LG, Lonning PE, Strausberg RL, Chanock S, Borresen-Dale AL, Perou CM: Mutation of GATA3 in human breast tumors. Oncogene 2004, 23:7669-7678.

24. Fujita N, Wade PA: Use of bifunctional cross-linking reagents in mapping genomic distribution of chromatin remodeling complexes. Methods 2004 , 33:81-85.

25. Langmead B, Trapnell C, Pop M, Salzberg S: Ultrafast and memory-efficient alignment of short DNA sequences to the human genome. Genome Biol 2009, 10:R25.

26. Heinz S, Benner C, Spann N, Bertolino E, Lin YC, Laslo P, Cheng JX, Murre C, Singh $\mathrm{H}$, Glass CK: Simple combinations of lineage-determining transcription factors prime cis-regulatory elements required for macrophage and B cell identities. Mol Cell 2010, 38:576-589.

27. Edgar R, Domrachev M, Lash AE: Gene Expression Omnibus: NCBI gene expression and hybridization array data repository. Nucleic Acids Res 2002, 30:207-210.
28. Nawaz Z, Lonard DM, Dennis AP, Smith $\mathrm{CL}$, O'Malley BW: Proteasome-dependent degradation of the human estrogen receptor. Proc Natl Acad Sci USA 1996, 96:1858-1862.

29. Yamashita M, Shinnakasu R, Asou H, Kimura M, Hasegawa A, Hashimoto K, Hatano N, Ogata M, Nakayama T: Ras-ERK MAPK cascade regulates GATA3 stability and Th2 differentiation through ubiquitin-proteasome pathway. J Biol Chem 2005, 280:29409-29419.

30. Bernardo GM, Lozada KL, Miedler JD, Harburg G, Hewitt SC, Mosley JD, Godwin AK, Korach KS, Visvader JE, Kaestner KH: FOXA1 is an essentia determinant of ERa expression and mammary ductal morphogenesis. Development 2010, 137:2045-2054.

31. Carroll JS, Meyer CA, Song J, Li W, Geistlinger TR, Eeckhoute J, Brodsky AS, Keeton EK, Fertuck KC, Hall GF, Wang Q, Bekiranov S, Sementchenko V, Fox EA, Silver PA, Gingeras TR, Liu XS, Brown M: Genome-wide analysis of estrogen receptor binding sites. Nat Genet 2006, 38:1289-1297.

32. Bates DL, Chen Y, Kim G, Guo L, Chen L: Crystal structures of multiple GATA zinc fingers bound to DNA reveal new insights into DNA recognition and self-association by GATA. J Mol Biol 2008, 381:1292-1306.

33. Raouf A, Zhao Y, To K, Stingl J, Delaney A, Barbara M, Iscove N, Jones S, McKinney S, Emerman J, Aparicio S, Marra M, Eaves C: Transcriptome analysis of the normal human mammary cell commitment and differentiation process. Cell Stem Cell 2008, 3:109-118.

34. Lin CY, Strom A, Vega VB, Kong SL, Yeo AL, Thomsen JS, Chan WC, Doray B, Bangarusamy DK, Ramasamy A, Vergara LA, Tang S, Chong A, Bajic VB, Miller LD, Gustafsson JA, Liu ET: Discovery of estrogen receptor alpha target genes and response elements in breast tumor cells. Genome Biol 2004, 5:R66

35. Prat A, Parker JS, Karginova O, Fan C, Livasy C, Herschkowitz Jl, He X, Perou CM: Phenotypic and molecular characterization of the claudin-low intrinsic subtype of breast cancer. Breast Cancer Res 2010, 12:R68.

36. Holliday D, Speirs V: Choosing the right cell line for breast cancer research. Breast Cancer Res 2011, 13:215

37. Loi S, Sotiriou C, Haibe-Kains B, Lallemand F, Conus N, Piccart M, Speed T, McArthur G: Gene expression profiling identifies activated growth factor signaling in poor prognosis (Luminal-B) estrogen receptor positive breast cancer. BMC Med Genomics 2009, 2:37.

38. Creighton CJ: The molecular profile of luminal B breast cancer. Biol Targets Ther 2012, 6:289-297.

39. Tran B, Bedard P: Luminal-B breast cancer and novel therapeutic targets. Breast Cancer Res 2011, 13:221.

40. Cui X, Schiff R, Arpino G, Osborne CK, Lee AV: Biology of progesterone receptor loss in breast cancer and its implications for endocrine therapy. J Clin Oncol 2005, 23:7721-7735.

41. Richer JK, Jacobsen BM, Manning NG, Abel MG, Wolf DM, Horwitz KB: Differential gene regulation by the two progesterone receptor isoforms in human breast cancer cells. J Biol Chem 2002, 277:5209-5218.

doi:10.1186/1471-2407-14-278

Cite this article as: Adomas et al:: Breast tumor specific mutation in GATA3 affects physiological mechanisms regulating transcription factor turnover. BMC Cancer 2014 14:278.

\section{Submit your next manuscript to BioMed Central and take full advantage of:}

- Convenient online submission

- Thorough peer review

- No space constraints or color figure charges

- Immediate publication on acceptance

- Inclusion in PubMed, CAS, Scopus and Google Scholar

- Research which is freely available for redistribution 